\title{
Aging and feminine body: conceptions of women after menopause
}

\begin{abstract}
The aging represents a period in the development that extends throughout human life. In Western culture, the condition of aging can be stigmatized socially, considering that old age is often reduced to physical and mental disability, in addition to being considered a socially unproductive phase. In the case of women, the stigma of old age rests heavily on the body, especially in the climacteric period and the arrival of menopause. This descriptive-exploratory study aimed to analyze the report of five women in a State of menopause or who have already reached menopause between 49 and 60 years, about aging, femininity, sexuality and body. Data collection occurred through a half structured interview that is it recorded in audio and transcribed fully, in thematic content analysis. The results show the categories:
\end{abstract}

a. Sexual and reproductive health

b. Body, aesthetics and self-care.

c. Sexual education and reactions before the menarche and menopause.

d. Conceptions of femininity and sexuality.

e. Conceptions about the aging.

The reports uphold in ideal images, with stereotypes that limit the autonomy. The data points to the necessity for the opportunity to reflections that can lead to better quality of life by understanding the phenomenon of aging feminine, before the current standards of aesthetics and beauty. It is concluded that it is necessary to deepen the research relating to aging social senses about femininity, to support proposals of preventive intervention in the field of education, psychology and medical clinic.
Volume 3 Issue I - 2018

Amanda Candido, Ana Claudia Maia Bortolozzi, Olga Maria Rolim Piazentin Rao Professor, Department of Psychology, Sao Paulo State University, Brazil

Correspondence: Olga Maria Rolim Piazentin Rao, Department of Psychology Postgraduate Program in Developmental and Learning Psychology Sao Paulo State University, Brazil, Email olgarolim29@gmail.com

Received: November 28, 2017 | Published:January 05, 2017

Keywords: aging, sexuality, women

\section{Introduction}

Aging is a phenomenon of multiple dimensions that affects people over your human development. It's set on various perspectives which include biological, psychological changes and/or inevitable social this stage of human life. ${ }^{1}$ In Brazil, the current elderly population already exceeds 26.1 million people of which $51.5 \%$ are women. ${ }^{2}$

Sexuality can be understood as a broad concept that is configured on the individual erotic from a diffuse predisposition shaped according to the individual experiences of the subject, mediated by values, ideals and cultural models. ${ }^{3}$ It is, therefore, cultural product that is for all ages and special features about the manner in which it is expressed and is felt and experienced by each individual. Significant biological changes that are felt at that time of life often interfere in the way they relate to the elderly with others and with your own body and the experience of sexuality. ${ }^{4}$ It should be noted that the biological changes are present throughout the life cycle, but in old age, can represent a need for upgrading and reformulation of your own concept since youth and adulthood are periods in which the sexual performance is valued socially.

Some people feel the transition to old age as a significant loss in front of intercourse satisfaction and difficulties of acceptance that your body is no longer the young body that presents the same characteristics. In addition to the physical and psychological factors, the stage of old age brings also change in the roles and social position to which the individual is related. According to $\mathrm{Haddad}^{5}$ doctors, psychologists and social scientists point out that the elderly need to be savvy about their biological conditions and limitations, and the need to keep active and integrate socially. Old age itself turns out to be a socially stigmatized period as difficult and bad men and women differ, each corresponding to the concerns of culture to male and feminine gender assumptions.

The changes that permeate the aging process happen regardless of the genre; however, women undergo a sharper break when they are in the transition from middle age and old age ${ }^{6}$ and because they are the main milestone the biopsychosocial sudden drop of hormones responsible for reproduction ${ }^{1}$ that directly affects the most significant changes of the body. According to the definition of the World Health Organization, the climacteric is a biological phase of a woman's life other than a pathological process comprising the transition between your reproductive period. This phase begins with individual variations-around 45 years and may extend up to the 50 to 55 years, scoring mainly by last menstrual cycle or menopause. ${ }^{7}$ 
In addition to the biological changes triggered by menopause, the perception of the feminine body changes and implies in various strategies to establish and adapt to a new body image formed. Although the climacteric doesn't involve in a direct relationship with the admission of women in old age, for many years the feminine image, according to the medical model, was associated with your ability to bear children. ${ }^{8}$ In this sense, the woman in aging feel their social privileges weaken, as if unable to match standards perceives social.

Gender is a social construct and in this sense, being a woman goes beyond the exclusively organic issues ${ }^{1}$. Considering the construction of the feminine gender the patterns created on the beauty imply a form of dominance assumed by a sexist society. To Naomi Wolf, ${ }^{9}$

The " beauty ' is a monetary system similar to the gold standard. Like any system, it is determined by the policy and, in the modern era in the Western world, is the last and best set of beliefs to keep intact the male domain. To assign value to women in a vertical hierarchy, according to a physical standard imposed culturally, he expresses power relationships that women need to compete so unnatural for resources of which men have appropriated.

The concept of beauty has undergone changes according to the season and civilization in the history of humanity, however, is always related to the maintenance of the juvenile aspect. ${ }^{7}$ As a way to preserve the value assigned to your body through the beauty and youth, some women opt for cosmetic procedures and surgeries. These strategies involve the depersonalization of women, considering that she waive your own subjectivity in favor of a model which should follow. This process can corroborate in existential emptiness marked especially when the body, for biological reasons, no longer correspond to the concerns of culture. ${ }^{1}$

The change in body aesthetics, between youth and old age, can cause emotional changes that permeate the sexuality in aging. In addition, the psychological factors allies to organic changes contribute to a greater or lesser acceptance of General changes, caused by advancing age. ${ }^{4}$

Organic changes, anatomical and functional, in aging male and feminine are reported in several studies. However, how people react emotionally in the face of these changes, especially aesthetic standards in force is still a matter to be explored, in order to better understand the feminine representation in Aging on your self-image built socially and under the changes with age. Given this, this descriptive-exploratory research aimed to analyze the report of women who have reached menopause on Aging, femininity, sexuality and body.

\section{Material and methods}

\section{Participants}

Five women, aged between 49 and 60 years, in a State of menopause having reached menopause between 42 and 51 years of them four were married and a separate. The sample was characterized as "convenience" according to the purposes for a qualitative research. The participants were named with the letter P (uppercase), followed by the Arabic number.

\section{Procedures}

Selection of the sample: The women were selected from the criterion of being in climacteric period, regardless of marital status, age or other conditions. For recruitment, we used the technique of "snowball", in which a indicated other, constituting therefore a convenience sample. All ethical procedures were respected: approval by an Ethics Committee, clarification of objectives and method, signature of informed consent.

Data collection: For data collection used a screenplay of interview containing questions covering five areas of research: body, sexuality, sex education, aging and representativeness. Days and scheduled timetable at the residence of the participants, in a reserved room and without interruptions, the interviews were carried out individually. They had the minimum duration of 29 minutes and maximum of 46 minutes.

Data analysis: The verbal interaction was recorded in audio and subsequently transcribed. The technique used was the thematic content analysis, proposed by Bardin ${ }^{10}$ consisting of elaboration of categories representing, comprehensive and mutually exclusive.

\section{Results and discussion}

The results will be presented from the five categories emerging from the analysis, presented in Figure 1.

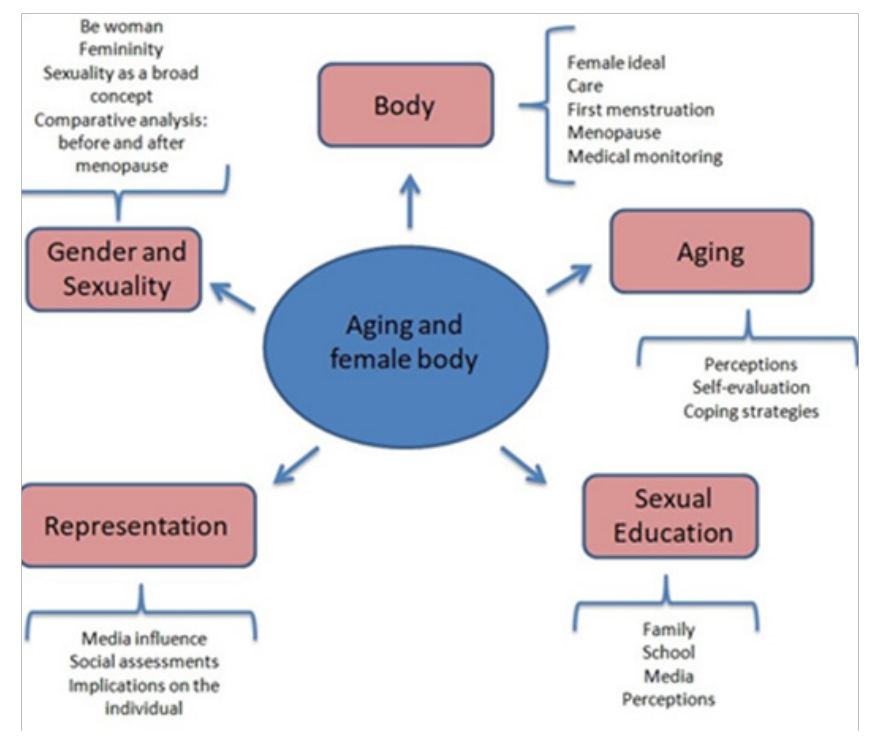

Figure I Scheme of thematic analysis categories.

\section{Sexual and reproductive health}

The first sexual intercourse of participants took place between 17 and 22 years. The number of births, P1, P4 and P5 had three births each, and eight of them, natural. In one of the Parthians the baby was premature and died. P2 and P3 reported two births, being these, and cesarean sections a miscarriage. Among the participants, only P5 reported having contracted candidiasis and the others say they never had a gynecological disease. P1 and P5 perform surgery to remove the uterus because of polyps and a fibroid, respectively. The frequency to the gynecologist (self-care) was reported as being "once a year" by P1, P4 and P5. P2 and P3 assumed not to go to doctors gynecologists since the birth of the last child. The sexual and reproductive life of these women it depicts sexual practices common in our Western society. ${ }^{11,12}$ What draws attention is the low frequency to the gynecologist, noting the low adherence to preventive care in sexual health, as well as noted in the literature. ${ }^{12-14}$ 


\section{Body, aesthetics and self-care}

The feminine body ideal, for these women, in General, prioritized the image of a body that matches the social standards of beauty in the West: big breasts, small waist, firm skin, no belly, skinny body (P1, P3, P4). P1 concluded that the ideal body would be "everything that she's not".

Oh, a beautiful breast and big guy, a thin waist, a relatively wide hips, without belly! Without belly! That's all I have no (laughs). I think I wanted to be so right (P1, 56 years)

Two participants scored a body ideal is one that brings satisfaction to the person (P2), or one that is healthy, in which the person feels well and beautiful without the need of esthetic interventions (P5).

I think first of all is being healthy, because there's no point in being cute and don't have health. [...] Have a beautiful face, perfect body, you don't have to be looking for things to make statement, moisturize. I think the beautiful person you don't need any of that (P5, 58 years).

Aesthetic standard of beauty, strongly marked in the speeches and existing cultural artifacts ${ }^{9}$ is reproduced in the speech of some women away from them, with the physical changes of aging, this standard of beauty, which, for others is bound to a body " healthy and satisfying, without surgical repair. This suggests that, even in these cases, the reference is normative standard because the satisfaction is in the body that didn't need repairs.

As for body care, regular physical activities and nutrition were important conditions cited for the health of the body, despite the currently difficult to represent menopause establish behaviors accordingly. P1 says that takes care of the body doing regular physical activities, cosmetic procedures and abdominoplasty, P2 through balanced diet and it is not considered a vain woman. The end P3 takes care of the body with nutrition and regular physical exercises, and their care have been expanded after menopause, because it realized that your body was changing and that she should spend more time taking care of themselves, as a way of coping with transformations of menopause. Such changes were also perceived by two other participants. P4 cited the reduced power and sporadic exercises and P5 scored the daily care with the aesthetics, though both have realized that the willingness to take care of themselves decreased with the arrival of menopause.

I'm kind of lacking. Physical activity is zero. I tell my doctor that my physical activity is taking care of the House, going up stairs, down stairs (laughs). What I do as well is to pass a cream, but no big deal. I'm not worried about wrinkles, body, chest dropping, no, I'm good. I think I lost a little disposition to do things, so I think you become a little slower ... [...] I think that's what I'm sinning, because you should be doing some physical activity, should be caring more, do a gym, because of the bones, available. (P5, 58 years).

The data show that the info on the care of the health of the body is aware of them, although not always ensure healthy habits. ${ }^{12,13}$ It seems that the arrival of the climacteric is a time when women are concerned more with food and exercise, not as a form of prevention, but as a means to alleviate or slow the changes limiting body aged. ${ }^{1}$

\section{Sexual education and reactions before the menarche and menopause}

The women interviewed reported a sexual education remiss in family context. P4 stressed about the contradiction between the lack of providing information and expect certain behaviors related to sexuality. P3 pointed about innocence that had even when in adulthood:

It was all in school. Birth control, these things; because no one was talking about it, spoke only when appeared pregnant at home (laughs (P4, 49 years).

Look, I think it was me and him, he and I. After I married I learned in practice! Of course, at the time I could hear some things, but I didn't have the vision that I have today. So it was like this: I got pregnant? It's got to come out! Entered, will have to leave. (laughs) (P3, 53 years).

In addition, other sources of information were part of the education I received, as can be seen in Table 1.

Table I Sources of information about sexuality in sexual education of the participants

\begin{tabular}{|c|c|c|c|c|}
\hline $\begin{array}{l}\text { Women } \\
\text { participants }\end{array}$ & Family & School & Media & $\begin{array}{l}\text { Other forms of } \\
\text { sexual education }\end{array}$ \\
\hline PI & Silent and conservative & $\begin{array}{l}\text { Content restricted to biological vision and } \\
\text { separately for boys and girls }\end{array}$ & $\begin{array}{l}\text { Books and novels as } \\
\text { major sources }\end{array}$ & $\begin{array}{l}\text { Through friends and } \\
\text { practical experiences } \\
\text { with the partner }\end{array}$ \\
\hline P2 & $\begin{array}{l}\text { Silent and conservative (sister } \\
\text { as main source of model and } \\
\text { information) }\end{array}$ & $\begin{array}{l}\text { Biological vision and restricted the content } \\
\text { of reproductive health }\end{array}$ & $\begin{array}{l}\text { Not as a factor in } \\
\text { learning }\end{array}$ & $\begin{array}{l}\text { Through friends and } \\
\text { practical experiences } \\
\text { with the partner }\end{array}$ \\
\hline P3 & Silent and conservative & $\begin{array}{l}\text { Biological vision and restricted the content } \\
\text { of reproductive health }\end{array}$ & $\begin{array}{l}\text { Pornography and TV } \\
\text { shows }\end{array}$ & $\begin{array}{l}\text { Practical experiences } \\
\text { with the partner }\end{array}$ \\
\hline P4 & Patrulling and moralist & $\begin{array}{l}\text { Biological vision and restricted the content } \\
\text { of reproductive health }\end{array}$ & $\begin{array}{l}\text { Not as a factor in } \\
\text { learning }\end{array}$ & $\begin{array}{l}\text { Friends and pratical } \\
\text { experiences }\end{array}$ \\
\hline P5 & Silent and conservative & $\begin{array}{l}\text { Biological vision and restricted the content } \\
\text { of reproductive health }\end{array}$ & $\begin{array}{l}\text { Informational } \\
\text { magazines }\end{array}$ & $\begin{array}{l}\text { Friends, doctors and } \\
\text { practical experiences }\end{array}$ \\
\hline
\end{tabular}

The sexual education of women participants was generally muted and conservative and the knowledge acquired restricted an organic vision of sexuality, focused on genitality and on reproductive health.
The media proved how representative channel for some of them and a source of information. ${ }^{15}$ Such data relate directly with the conceptions of sexuality and femininity raised by participants, in order that our 
perceptions of sexuality reflect sexual education received during childhood and the way sexual manifestations are experienced. ${ }^{16}$

In relation to the perception of menarche and menopause, there was a clear difference of knowledge between the phenomena. The participating subjects menstruated for the first time between 12 and 17 years, P1 and P3 didn't know what it was period when experienced menarche, causing a surprise at the time of the event.

I remember I was with 14 years in the backyard of my house. I was scared because I thought I had hurt myself [...] [About telling someone], because in the past I would die of shame, huh? Was a shame! I found out right at school and friends. Was little friend I've ever had to go through that, I commented and she ... was where he opened my little head (P1, 56 years).

P5 knew what it was, but got scared when it happened with her and considered the negative experience in your account. P2 considered the experience of menarche "quiet" for having an older sister who was selling and preparing her for this event and P4 already had knowledge by having more maturity and socialize with people who have already had your period, because she had a period with 17 years. The matter was treated as taboo for them at the time, and only P3 and P5 counted on menarche for mothers, asking for help. P4 pointed out that had very strong cramps to the point of feeling nauseous, but I did not seek help with family or doctors. The school's performed as a common factor among the participants of the sample as a source of information about menstruation. The reports go to the meeting of authors who talk about the difficulties of dialogue about sexuality in the family. As a taboo, this subject even today appears in a family sex education silent and limited..$^{16,17}$

On the other hand, the perception of menopause was shared with family or friends for P1, P3, P4 and P5. P1 realized the State of climacteric and menopause through symptoms such as hot flashes, irritability and indisposition. P2 has not presented any symptoms and menopause only when your periods stopped and never came back.

Oh, just stopped [period]. I think the last two times I came, came and stopped. I had nothing, no symptoms, nothing would stop and then came back, it was so good of nothing. (P2, 60 years).

P3 pointed out that your menstrual cycle was irregular for a few months and after a while she stopped menstruating at once. P4 noticed a drop in libido, indisposition, irregular menstrual cycle and heat waves. P5 noticed skin dryness, loss of libido, discouragement, indisposition, hot flashes and loss of lubrication. One can see that the obvious symptoms of changes in the body, or only the interruption of menstruation is eventually unavoidable evidence for the recognition of the end of reproductive life..$^{18-22}$

P1, P4 and P5, after menopause, do regular gynecological followup and only P5 does hormone replacement. The three participants who attend a gynecologist regularly showed divergent models of care. P1 reported that your doctor always explained about the condition of menopause since when needed to make the removal of the uterus in surgery and he suggested natural alternatives for dealing with the symptoms of menopause, which your doctor if scored P4 shows so insensitive before your suffering and brings no alternatives to deal with the symptoms, claiming that "it's part of the process" and said having a doctor very P5 explanation which you provided information about menopause and hormone replacement suggested for your daily well-being Although the medication can cherish in negative consequences to the body.

The first thing is that the skin very dry, heat a lot, especially at night, you feel that heat in the neck area, you lose lubrication, is too dry. That's when I realized and I went to the gynecologist. Then he told me "well, you're going to have to take hormone" and I said "but you hear about so badly, that they give you cancer," but he said "we have to think on your quality of life! I'll give you a low dosage that is more to improve your skin, dryness, your bones, your hair "and you will see the changes [...] (P5, 58 years).

It should be noted, worryingly, the inability of health professionals, in the case of physicians, in dealing with the psychological and social issues under the organic changes of women. So, it is very important to a multidisciplinary health care work for integrated service of various professionals.

\section{Conceptions of femininity and sexuality}

When questioned about the meaning of being a woman, P1 and P3 associated to the social role of being a "housewife".

Woman suffers us! Is everything, everything, everything is the woman. Child will not talk with father, son conversation with mom Problem not going straight to Dad passes first through the mother, the woman, the poor woman. But we have some advantages, it is not all negative. When you want the things you can do, being a woman is a beauty in these hours [...] Oh, I guess that woman is woman, okay? Woman's gotta have femininity! It never hurts to show the beauty that she has to show ( $\mathrm{P} 1,56$ years).

The impression it gives me is that it's like a centipede that has many activities and has to unfold in many things. The man, he has to work and put the money in the House, but is it there and just. Now the woman is washing, ironing, cooking, kids, so is fire! I think so (P3, 53 years).

P1 and P5 relate the feminine gender to power of conquest and seduction, classifying the woman as a human being "sexy and linked to desire". All the sample of participant's social role woman correlated to be "mom".

You can realize a ambivalence between the speeches, for $\mathrm{P} 1$ and $\mathrm{P} 3$ scored the woman as something tiring and negative, even to bring the idea of being a mother as a ' gift ' exclusively for women. Regarding femininity, the participants presented difficulty in defining concepts, but P1 related femininity with wearing clothes that make a woman attractive, like skirts, necklines, dresses and a good physical shape, according to Western standards.

P2 and P3 associated to vanity, while P4 and P5 to feel beautiful and attractive. P5 still pointed out that a feminine woman is one who arouses desire and pleases the husband or partner. Of course the participants reproduce social stereotypes about what it means to be a woman and the representation of femininity is associated with social standards and limiting gender relations..$^{23,24}$

Interestingly, the image of the beautiful woman sexually appears related to submission to man, a condition to please a man and not as a liberation front of repressive standards of yore about feminine desire; in other words, we're not heteronormative and patriarchal patterns imposed on conjugality, as Maia. ${ }^{25}$ 
The case of conceptions in sexuality, P1 and P2 have associated the concept of sexuality with the sexual practice, P3 scored as the name to describe feminine or male, $\mathrm{P} 4$ and $\mathrm{P} 5$ reported that sexuality is to feel attractive and the ability to arouse sexual interest in somebody playing the limited concept of sexuality to genitality, as postulates Maia ${ }^{3}$ After the researcher to explain better the concept, the participants could review his speeches so they understand the various aspects that should be considered when talking about sexuality and understand the manifestations of sexuality also on issues of gender, body and affectivity. As questioned about the variation of sexuality before and after menopause, P2 points out that "is quiet and doesn't care about that," while P1, P3, P4 and P5 described expressions of sexuality and its transformations at different levels, which can be exemplified by the report P1:

Oh, you're dry, loses the lubrication, the interest although I have said that he [sex] is good pretty much decreases decreases. Needs to be much more, as I speak ... Oh, the story needs to be much more well told to get at one point before you talked about an "A" and already arrived, you understand? (...) So it's pretty out there, the interest is no longer all that.. [...] I don't know why when we're younger, we have all that freshness, that life; We feel most desired (...) Now going through menopause sometimes you think, you think "Wow, I'm not prettier" or when the person looks at you and you think "is that she doesn't want me? I don't think she thinks I'm more beautiful, desired ". But on the other hand, sometimes you think yes, that you want Yes! Some things you see, how you feel, that you look, then realizes he's still Yes, but the woman who enters that stage [menopause] feels right "the flip side", it's not so much more, it's not so much more! But I feel much loved, he [husband] love me even when I can't (laughs). I think it's because I always got great care, too! Then automatically you repay it. Of course once in a while there's something, isn't it also just flowers, right? But the affection the people there is a way to acknowledge what the other is doing, the way he is treating you. Here's the deal, my relationship is still the same, same.

Figure 2 illustrates with image, the social representations of the concepts analyzed most marked in this category.

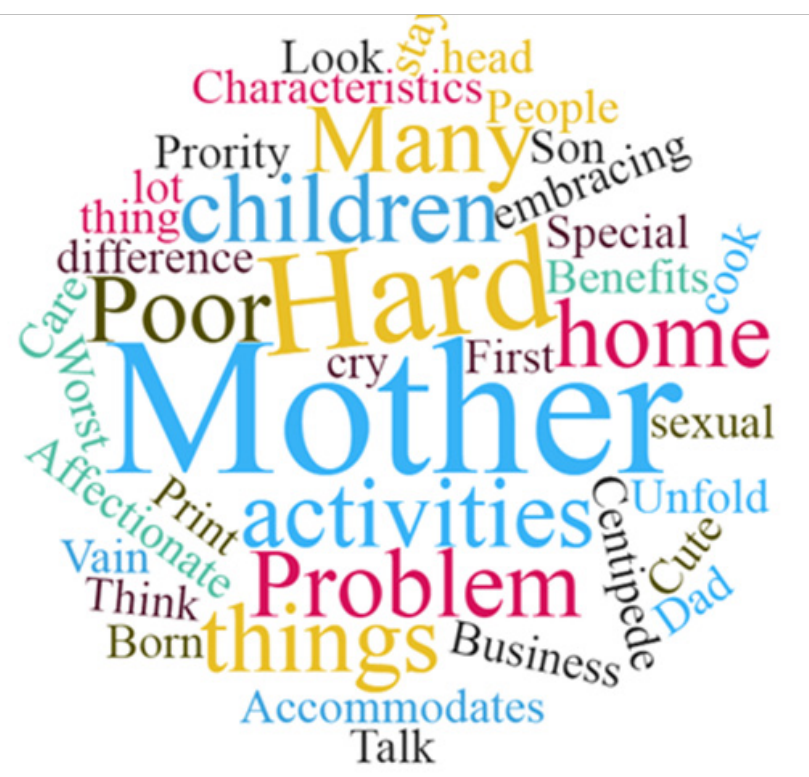

Figure 2 Cloud of recurring words correlated to be woman.

\section{Conceptions on aging}

Aging was seen as something natural and wonderful for P1, P2 and P3, while for P4 and P5 is a process that must happen.

Getting old? I have a good vision on this, I think, I think it's cool. Many try to resources, I think it's cool. I think it's nice to see people getting older, (P3, 53 years).

Well, getting older has a main condition: be healthy right? Because so ageing well has to be healthy, healthy you do any business. Nowadays there are a lot of things to elderly person, I just don't have fun who doesn't want ( $\mathrm{P} 4,49$ years).

$\mathrm{P} 1$ pointed out the absence of commitment to family or work and the possibility to travel wherever possible as positive aspects of aging and the limitations and conditions such as negative aspects. P2 considered that everyone ages differently and so, the positive and negative aspects will be different for each. P3 reported about maturity while positive aspect of aging and loss of vitality as a negative component of the common old age process. P4 stressed that the positive side of aging is conditioned by the health and the downside would be the reliance on others to perform tasks. P5 pointed out the experience and addiction as positive and negative factors, respectively. You can see that aging is rated by them flexibly, to the extent that raise positive and negative aspects, organic and social references, favorable aspects in social relations and also personal (maturity), etc.

In the perception of aging themselves, only P3 and P5 pointed to be aging, because see aging in indisposition and biopsychosocial transformation which they fall.

P1 denied that is aging and even denies the possibility of growing old. P2 and P4 have reported noticing changes, but they feel young "head". Many studies show the difficulties of women and men to accept this stage of life. ${ }^{18-22}$ As for coping strategies associated with the aging feminine, $\mathrm{P} 1$ suggested exercising regularly, in order to improve mood and self-esteem. Exercises, a lot of exercise! I've always liked. There knowing it was good to do at this stage, anything to get through menopause there you "get head", right? Since I don't want to take pills, I don't want to feel everything that felt so come on! You feel, but it's much more bearable with the exercises ( $\mathrm{P} 1,56$ years). $\mathrm{P} 2$ reported that genetics should be primary component to understand the aging process in the life of each person, because in your life story had many similar experiences with your mother or sister. P3 pointed suggestion exposure in environments with older people to have better sense of old age and bring her to the real plan. P4 stressed about information as a source of face the menopause and aging processes with more quality of life and P5 reported about the support that should be provided by professionals such as doctors and psychologists to assist this transition, especially for those who deny the aging. Once again, the role of professionals in attendance to women in aging looks like an important discussion.

\section{Final considerations}

The speech of these women was crossed by body image considered "ideal", highlighting the changes that break with social standards were, in this case, most significant physiological changes. In addition, the existence of a pattern of feminine gender stereotypes that limit loaded autonomy: the need to please the partner and/or take care of himself, as a principle of "being a woman", regardless of the conditions of aging and changes caused by menopause. Stresses, therefore, the 
importance of dialogue and reflect on gender and sexuality at women, minimizing the social influences that lead to suffering and helping to provide information that would enable their sexuality and understand experiences while rights personal.

Should be considered the limits of research due to the small sample and the characteristics of participants who may have influenced the results, such as the fact that all of them be mothers and heterosexuals, beyond socioeconomic condition, which can be the determining factor for Some embedded social roles and conceptions of sexuality while broad concept. Future research may explore other variables and enrich this discussion.

\section{Acknowledgements}

We would like to thank $\mathrm{CNPq}$ for the scientific initiation scholarship that financed the realization of this survey.

\section{Conflicts of interest}

Author declares that there are no conflicts of interest.

\section{References}

1. Ferreira VNO. envelhecimento feminino na sociedade do espetáculo. Dissertação Juiz de Fora, 2010. p. 1-132.

2. Instituto Brasileiro de Geografia e Estatística. Pesquisa Nacional Por Amostra de Domicílios, Síntese de Indicadores: Idosos já são 13\% da população e país tem menos crianças. IBGE. 2013.

3. Maia ACB. Conceito amplo de sexualidade no processo de educação sexual. Psicopedagogia Online. 2010;1:1-11.

4. Pascual CPA. sexualidade do idoso vista com novo olhar. Loyola, Brazil; 2002 .

5. Haddad EGM. A ideologia da velhice. Cortez, São Paulo, Brazil; 1986.

6. Beauvoir SO. Segundo sexo. Originalmente publicado em, Rio de Janeiro, Brazil; 2009.

7. Martins NTCR.Sexualidade e envelhecimento na percepção de pessoas idosas. Dissertação de Mestrado. Pós-Graduação em Psicologia do Desenvolvimento e Aprendizagem, Bauru, Brazil; 2012.

8. Matos MIS, Soihet RO. Corpo feminino em debate. Brazil; 2003.

9. Wolf NO. Mito da beleza: como as imagens de beleza são usadas contra as mulheres. In: Rocco, editor. Rio de Janeiro, Brazil; 1992.
10. Bardin L. Análise de Conteúdo. Edições 70, Portugal; 2009.

11. Heilborn ML. Entre as tramas da Entre as tramas da sexualidade brasileira sexualidade brasileira. Estudos Feministas, Florianópolis. 2006;14(1):43-59.

12. Martins APV. Visões do feminino: a medicina da mulher nos séculos XIX e XX. Rio de Janeiro: Fiocruz, Brazil; 2004.

13. Bydlowski CR, Westphal MF, Pereira IMTB. Promoção da saúde: porque sim e porque ainda não! Saúde e Sociedade. 2004;13(1):14-24 .

14. Heilborn ML. Articulando gênero, sexo e sexualidade: diferenças na saúde. In: Goldenberg P, Marsiglia RMG, editors. O Clássico e o Novo: tendências, objetos e abordagens em ciências sociais e saúde. 2003. p. $1-208$.

15. Fischer RMB. Mídia e educação da mulher: uma discussão teórica sobre discussão teórica sobre modos de enunciar o feminino na TV. Estudos Feministas. 2001.

16. Spaziani RB, Pereira PC, Maia ACB. Memórias da Educação Sexual: relatos de educadoras sobre a infância e adolescência. Revista IberoAmericana de Estudos em Educação. 2014;9(3):646-655.

17. Spaziani R, Maia ACB. Educação para a sexualidade na infância: ações e concepções da escola e da família. SP: Margem da Palavra. Bragança Paulista, Brazil; 2017. p. 1-100.

18. Butler R, Lewis M. Sexo e amor na 3a idade. Brazil; 1985.

19. Guitierrez E. Mulher na menopausa: declínio ou renovação. In: Rosa dos tempos, editor. Brazil; 1992.

20. Lopes G, Maia M. Sexualidade e envelhecimento: envelhe sendo com sexo. Saraiva, Brazil; 1994.

21. Rosenthal SH. Sexo depois dos 40, 50, 60 e 70. Rio de janeiro: Records, Brazil; 1993.

22. Sand G. Está quente aqui ou sou eu? São Paulo: Summus, Brazil; 1995.

23. Belotti G. Educar para a Submissão-o (des) condicionamento da mulher. Vozes, São Paulo, Brazil; 1979.

24. Louro GL, Felipe J, Goellner SV. Corpo, Gênero e Sexualidade-um debate contemporâneo na educação, 3rd edn. Petrópolis, RJ: Vozes, 2007. p. 1-191.

25. Maia ACBA. educação sexual repressiva: padrões definidores de normalidade. In: Souza CBG, Ribeiro PRM Sexualidade, editors diversidade e culturas escolares: contribuições ibero-americanas para estudos de educação, gênero e valores. Araraquara: FCLar-UNESP Lab, 2008. p. 67-83. 